\title{
Faktor-Faktor Kesulitan Belajar Siswa pada Materi Perbandingan dengan Menggunakan Pendekatan Kontekstual
}

\author{
Yuni Agnesti' ${ }^{1}$ Risma Amelia ${ }^{2 *}$ \\ Pendidikan Matematika, IKIP Siliwangi \\ Jalan Terusan Jend. Sudirman, Baros, Kota Cimahi, Jawa Barat, Indonesia \\ 1yuniagnesti168@gmail.com; ${ }^{2 *}$ rismaamelia@ikipsiliwangi.com
}

Artikel diterima: 29-09-2020, direvisi: 23-05-2021, diterbitkan: 31-05-2021

\begin{abstract}
Abstrak
Mempelajari matematika dianggap sulit oleh mayoritas siswa. Solusinya, peneliti menerapkan sebuah pendekatan pembelajaran kontekstual. Penelitian ini bertujuan untuk menyelidiki faktor-faktor penyebab kesulitan siswa dalam mempelajari materi perbandingan. Penelitian deskriptif kualitatif ini menggunakan instrumen soal cerita berjumlah 3 soal. Subjek penelitian adalah 24 orang siswa yang dipilih secara purposive sampling pada salah satu SMP di Kabupaten Bandung Barat. Pengumpulan data dilakukan dengan menggunakan tes dan wawancara. Hasil penelitian kemudian dianalisis secara deskriptif untuk mencapai tujuan penelitian. Hasil penelitian menunjukkan bahwa siswa SMP Pasundan Rongga belum sepenuhnya mencapai target yang diharapkan. Siswa masih banyak yang mengalami kesulitan untuk menyelesaikan soal cerita. Kesulitan siswa yang dominan dapat dikategorikan ke dalam tiga bentuk, yaitu kurangnya pemahaman konsep, tergesa-gesa menyelesaikan soal, dan kurangnya memahami soal. Berdasarkan hasil wawancara, penyebab kesulitan tersebut karena siswa belum terbiasa diberikan soal berbentuk cerita. Soal cerita perlu lebih sering diberikan kepada siswa guna menambah pengalaman belajarnya.

Kata Kunci: Perbandingan, Pendekatan Kontekstual, Penyebab Kesulitan, Penelitian Kualitatif

\section{Factors of Student Learning Difficulties in Comparative Materials Using a Contextual Approach}

Abstract

Learning mathematics is considered difficult by the majority of students. The solution, researchers apply a contextual learning approach. This study aims to investigate the factors that cause students' difficulties in studying comparative material. This qualitative descriptive study used three-story questions as instruments. The research subjects were 24 students who were selected by purposive sampling at one of the junior high schools in West Bandung Regency. Data collection was carried out using tests and interviews. The research results were then analyzed descriptively to achieve the research objectives. The results showed that the students of SMP Pasundan Rongga had not fully achieved the expected targets. There are still many students who have difficulty solving story questions. The students' dominant difficulties can be categorized into three forms, namely a lack of understanding of the concept, rushing to solve the problem, and a lack of understanding the problem. Based on the results of the interview, the cause of the difficulty was because students were not used to being given questions in the form of stories. Story questions need to be given to students more often in order to increase their learning experience.

Keywords: Comparison, Contextual Approach, Causes of Difficulty, Qualitative Research.
\end{abstract}

Mosharafa: Jumal Pendidikan Matematika

Volume 10, Nomor 2, Mei 2021

Copyright $\odot 2021$ Mosharafa: Jurnal Pendidikan Matematika 


\section{Pendahuluan}

Pendidikan berfungsi mengembangkan kemampuan dan mewujudkan watak serta peradaban bangsa yang berpamor dalam bentuk mencerdaskan kehidupan bangsa (Irawatie, Iswahyuni, \& Setyawati, 2019; Qizi, 2021). Tujuannya untuk mengembangkan potensi siswa agar menjadi manusia yang beriman dan bertakwa kepada Tuhan Yang Maha Esa, berakhlak mulia, berilmu, kreatif, dan menjadi warga negara yang demokratis serta bertanggung jawab (Anggoro, 2016; Komara, 2017).

Dalam kehidupan sehari-hari manusia sering dihadapkan pada masalah yang menuntut untuk diselesaikan, hal ini tidak terlepas dari pelajaran matematika (Fujii, 2018; Ferdianto \& Yesino, 2019; Shanta \& Wells, 2020). Pada kenyataannya, matematika kurang disukai dan dikuasai oleh kebanyakan siswa. Azwar (Rahayu, Mardiyana, \& Saputro, 2015) menjelaskan bahwa selalu ada mekanisme mental yang mengevaluasi, membentuk pandangan, mewarnai perasaan, dan akan menentukan kecenderungan sikap ataupun prilaku seseorang terhadap sesuatu yang sedang dihadapi.

Dewasa ini, banyak siswa berasumsi bahwa tujuan matematika adalah hanya untuk pintar berhitung (Fouze \& Amit, 2017; Agnesti \& Amelia, 2020). Padahal tujuan matematika lebih luas daripada itu. Matematika dapat membantu menyelesaikan berbagai permasalahan kehidupan sehari-hari, dan merupakan dasar ilmu (Simamora, Sidabutar, \& Surya, 2017; Surya \& Putri, 2017). Oleh sebab itu, matematika sangatlah penting untuk dipelajari, hal tersebut ditegaskan oleh Suherman (Durandt \& Jacobs, 2018; Agnesti \& Amelia 2020) bahwa matematika penting untuk membentuk sikap serta pola pikir.

Afriansyah (2017) mengemukakan pengalaman guru-guru dalam menempuh studinya selama kurang lebih 16 tahun. Para guru tersebut dominan memahami matematika karena terbiasa mengerjakan permasalahan yang diberikan selama sekolah.

Permasalahan dalam matematika tidak selalu berbentuk permasalahan rutin (Novriani \& Surya, 2017; Verschaffel, Depaepe, \& Van Dooren, 2020). Lidinillah (Indarwati, Wahyudi, \& Ratu, 2014; Aripin, 2018) mengemukakan bahwa masalah dalam pembelajaran matematika dapat disajikan dalam bentuk soal tidak rutin yaitu berupa soal cerita. Soal cerita yang dekat dengan kehidupan sehari-hari salah satunya dalam bentuk perbandingan (Hamidah, Putri, \& Somakim, 2018; Saputri, 2019). Perbandingan terdiri perbandingan senilai dan perbandingan berbalik nilai (Herminingtyas, 2019).

Materi perbandingan merupakan materi yang cukup sulit bagi siswa (Sari, 2020). Siswa banyak yang keliru dalam memodelkan dan menentukan jenis soal cerita materi perbandingan (Larasati \& Mampouw, 2018; Mulyadin, Sowanto, \& Dusalan, 2020). Soal cerita matematika ialah soal yang terkait dengan permasalahan kontekstual dan mewajibkan siswa untuk berpikir secara lebih dalam sehingga siswa cakap dalam memahami dan menetapkan hal yang diketahui serta ditanyakan pada soal, serta menyelesaikannya dengan langkah yang pas 
sehingga memperoleh hasil yang akurat (Rofi'ah, Ansori, \& Mawaddah, 2019; Walkington, Clinton, \& Sparks, 2019).

Menurut Khasanah (Toha, Mirza, \& Ahmad, 2018) soal cerita matematika adalah soal uraian yang menuntut seorang peserta didik mampu memahami dan menafsirkan soal yang pemecahannya memerlukan keterampilan dan kejelian. Jadi soal cerita cenderung sulit untuk diselesaikan, karena siswa harus benar benar menguasai terhadap konsep matematikanya.

Permasalahan tentang rendahnya hasil belajar matematika peserta didik serta kendala peserta didik dalam menangani soal cerita matematika (Yustianingsih, Syarifuddin, \& Yerizon, 2017; Putri, Winarni, \& Surya, 2021) mengindikasikan adanya kesalahan dalam proses belajar mengajar sehingga diperlukan adanya perbaikan. Permasalahan pembelajaran matematika tersebut didukung penelitian yang dilakukan oleh Darjiani (2015) dan Utari, Wardana, \& Damayani (2019) tentang analisis kesulitan belajar matematika dalam menyelesaian soal cerita. Hasil penelitiannya menjelaskan bahwa siswa mengalami kesulitan pada keterampilan berhitung, kesulitan dalam sudut pandang konsepsi, dan kesulitan dalam sudut pandang pemecahan masalah. Penyebab kesulitan belajar tersebut secara umum melingkupi minat dan motivasi, faktor guru, faktor lingkungan sosial dan faktor kurikulum.

Beberapa kesulitan siswa yang ditemukan dari hasil penelitian sebelumnya mengenai materi perbandingan perlu dianalisis lebih lanjut. Terutama dengan pendekatan kontekstual yang belum pernah diteliti sebelumnya. Jika diamati, materi perbandingan sangat sering kita gunakan dalam kehidupan sehari-hari sehingga sangat mungkin menjadi masalah kontekstual dalam matematika. Masalah kontekstual mengajarkan siswa menginterpretasikan suatu permasalahan, melihat sebuah masalah dalam kaca mata umum kemudian digunakan sebagai cara konkrit merepresentasikan konteks baru dan penanganan atas persoalan tersebut (Yuanita, Zulnaidi, \& Zakaria, 2018; Khusna \& Ulfah, 2021).

Penelitian mengenai faktor-faktor yang menyebabkan kesulitan siswa dalam belajar materi perbandingan dengan pendekatan kontekstual menjadi fokus penelitian ini. Tujuannya untuk mengetahui berbagai faktor penyebab kesulitan belajar siswa pada materi perbandingan dengan menggunakan pendekatan kontekstual dalam soal cerita. Dengan begitu, hasil penelitian akan membantu guru dalam menentukan langkah yang dapat dilakukan untuk meningkatkan hasil belajar siswa pada materi perbandingan.

\section{Metode}

Penelitian ini merupakan jenis penelitian deskriptif kualitatif (Yuliani, 2018). Subyek penelitian adalah siswa kelas VII A SMP Pasundan Rongga yang berjumlah 24 orang siswa. Data pada penelitian ini diperoleh dari hasil tes dan wawancara. Soal tes dalam penelitian ini yaitu soal yang berbentuk uraian dengan jumlah sebanyak 3 butir soal. Berikut adalah soal yang digunakan dalam penelitian (lihat Gambar 1). 
http://journal.institutpendidikan.ac.id/index.php/mosharafa

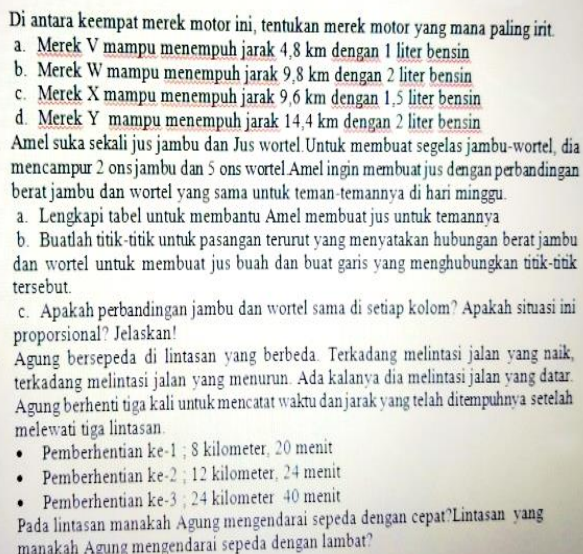

Gambar 1. Soal Uraian yang Diberikan.

Data hasil dari pengujian soal kemudian dianalisis secara deskriptif bersama dengan data hasil wawancara. Data tersebut ditriangulasikan dengan wawancara untuk mendapatkan data yang valid ketika mengerjakan tes.

\section{HaSil dan PEMBahasan}

Hasil analisis data dari soal-soal yang diujikan mengungkap bagaimana bentukbentuk kendala yang dialami saat siswa menyelesaikan soal cerita matematika kontekstual. Berikut merupakan rekapitulasi kesulitan yang dialami siswa berdasarkan jawaban siswa.

Tabel 1.

Kesulitan Siswa Saat Menyelesaikan Soal Cerita

\begin{tabular}{clll}
\hline Soal & Siswa 1 & \multicolumn{1}{c}{ Siswa 2 } & \multicolumn{1}{c}{ Siswa 3 } \\
\hline 1 & Siswa & Ketidakteliti & Tidak \\
tergesa-gesa & an saat & menyelesaika \\
proses & n soal karena \\
saat & kesulitan saat \\
& menyelesaika \\
& n soal. & & $\begin{array}{l}\text { penggunaan } \\
\text { konsep }\end{array}$ \\
& & & Tidak dapat \\
& Siswa tidak & Siswa & melanjutkan \\
& kampu & kesulitan & soal karena \\
& kengulitan \\
& konsep & & \\
\hline
\end{tabular}

\begin{tabular}{|c|c|c|c|}
\hline & & $\begin{array}{l}\text { mengaplika } \\
\text { n konsep }\end{array}$ & $\begin{array}{l}\text { terhadap } \\
\text { pengaplikasia } \\
\text { n konsep }\end{array}$ \\
\hline 3 & $\begin{array}{l}\text { Ketidaktelitia } \\
\text { n siswa saat } \\
\text { membaca } \\
\text { soal }\end{array}$ & $\begin{array}{l}\text { Siswa tidak } \\
\text { memahami } \\
\text { masalah } \\
\text { dari soal }\end{array}$ & $\begin{array}{l}\text { Kurangnya } \\
\text { penguasan } \\
\text { dan } \\
\text { pemahaman } \\
\text { konsep. }\end{array}$ \\
\hline
\end{tabular}

Berdasarkan tabel 1, kesulitan-kesulitan yang dialami oleh siswa yaitu pada soal nomor satu, siswa tergesa-gesa dan tidak teliti serta kurangnya penggunaan konsep. Pada soal nomor dua, siswa tidak menguasai dan tidak bisa mengaplikasikan konsep. Pada soal nomor tiga, tidak teliti saat membaca dan memahami soal, serta kurangnya penguasaan dan pemahaman terhadap konsep. Berdasarkan hasil wawancara, siswa mengemukakan bahwa soal cerita memang sulit untuk dipahami, apalagi ketika isi soalnya yang sangat panjang.

Berikut akan dipaparkan mengenai hasil jawaban siswa pada saat menyelesaikan soal cerita yang berkaitan dengan perbandingan.

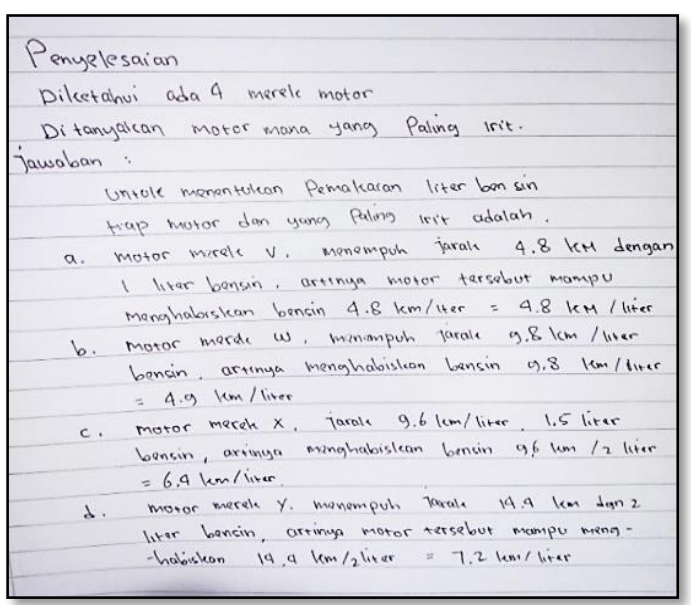

Gambar 2. Nomor 1 Jawaban Siswa Satu.

Gambar 2 merupakan jawaban siswa satu. Konsep yang diterapkan siswa dalam 
menjawab soal nomor satu sudah benar, namun siswa keliru pada saat menjawab bagian poin "d". Saat diwawancara, siswa mengemukakan bahwa pada proses menyelesaikan soal, ia tergesa-gesa, karena takut waktu habis.

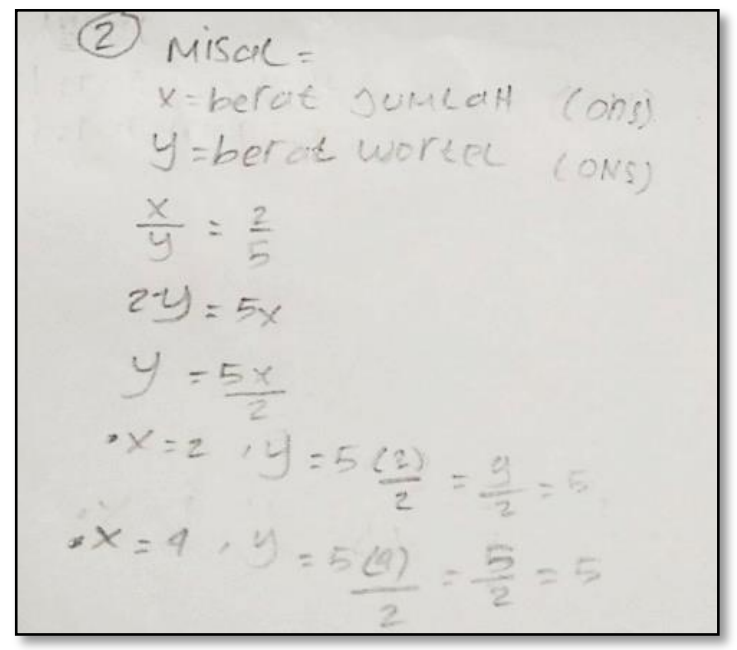

Gambar 3. Nomor 2 jawaban siswa Satu.

Pada Gambar 3, sebenarnya siswa sudah mampu menggunakan cara dengan benar, tetapi siswa lemah melakukan perhitungan dalam proses pembagian. Saat diwawancara siswa mengatakan bahwa siswa tidak menguasai konsep perkalian dan pembagian.

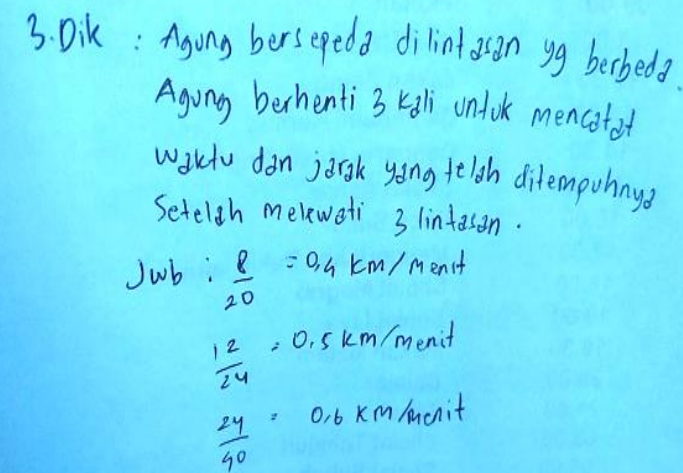

Gambar 4. Nomor 3 Jawaban Siswa Satu.
Pada Gambar 4, siswa menuliskan apa yang diketahui dari soal, bahkan jawaban siswapun benar. Siswa juga menguasai proses perhitungan. Namun, kekurangan siswa yaitu tidak dapat menyimpulkan jawaban dan siswa tidak teliti sat membaca soal. Pada soal tersebut dituliskan bahwa "Pada lintasan yang manakah Agung mengendarai sepeda dengan cepat? Pada intasan yang manakah Agung mengendarai sepeda dengan lambat". Siswa tampak mengabaikan pertanyaan tersebut. Saat diwawancara, siswa hanya fokus pada poin $a, b$, dan $c$ saja, sehingga pada pertanyaan yang harusnya disimpulkan tidak terjawab oleh siswa tersebut.

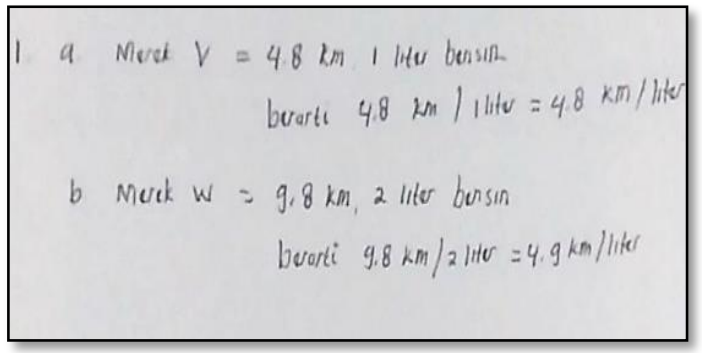

Gambar 5. Nomor 1 Jawaban Siswa Dua.

Pada Gambar 5, siswa tidak teliti dalam proses berhitung dan siswa juga tidak dapat menyelesaikan soalnya hingga akhir. Saat wawancara, siswa mengatakan bahwa kendala dalam menyelesaikan soal dalam kasus tersebut yaitu kurang memahami dalam teknik berhitung, sehingga dalam proses penyelesaian soal ini tidak dapat siswa selesaikan karena siswa kesulitan dalam melakukan perhitungan. 


$$
\begin{aligned}
& \text { (2) Diketahui : Wortel Jambua } \\
& \qquad \begin{array}{l}
x y=\frac{2}{5} \\
y y=5 x
\end{array}
\end{aligned}
$$

Gambar 6. Nomor 2 Jawaban Siswa Dua.

Pada Gambar 6, siswa tidak dapat melanjutkan proses jawabannya. Saat diwawancara, siswa mengatakan bahwa siswa tersebut kesulitan konsep apalagi yang harus dilakukan oleh siswa.

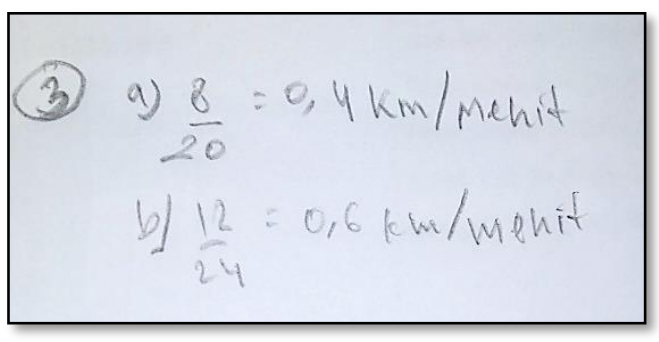

Gambar 7. Nomor 3 Jawaban Siswa Dua.

Pada Gambar 7, siswa langsung saja menjawab soal tanpa menuliskan apa yang diketahui dan ditanyakannya. Hasil wawancara, siswa mengatakan bahwa siswa kurangnya memahami masalah terhadap soal.

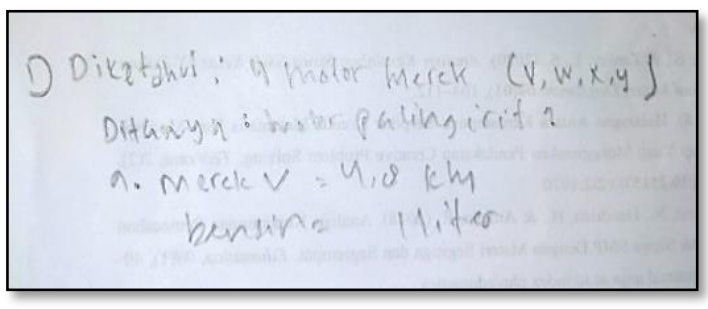

Gambar 8. Nomor 1 Jawaban Siswa Tiga.
Pada Gambar 8, kriteria penilaian dalam soal sudah muncul dimana siswa sudah menuliskan dari mulai yang diketahui dan ditanyakan dari soal, namun siswa sama sekali tidak menyelesaikan soal tersebut. Saat diwawancara, mengatakan bahwa siswa tidak memahami soal, siswa bingung bahwa konsep yang diterapkan dalam soal harus seperti apa, sehinggaa siswa kesulitan dalam menyelesaikan soal.

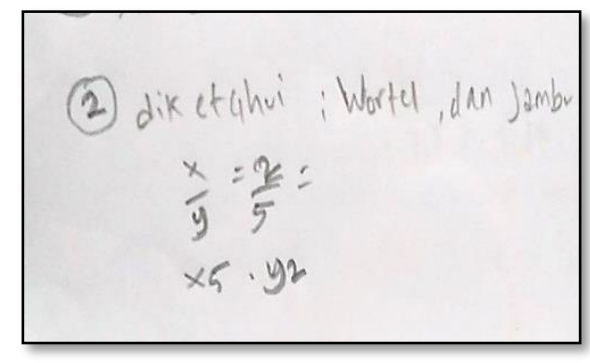

Gambar 9. Nomor 2 Jawaban Siswa Tiga.

Pada Gambar 9, langkah pertama yang dilakukan siswa dalam menjawab soal sudah benar, namun siswa melakukan konsepnya dengan cara menggunakan perkalian silang. Saat wawancara, ia tidak paham apa yang seharusnya dilakukan dalam melanjutkan jawaban tersebut.

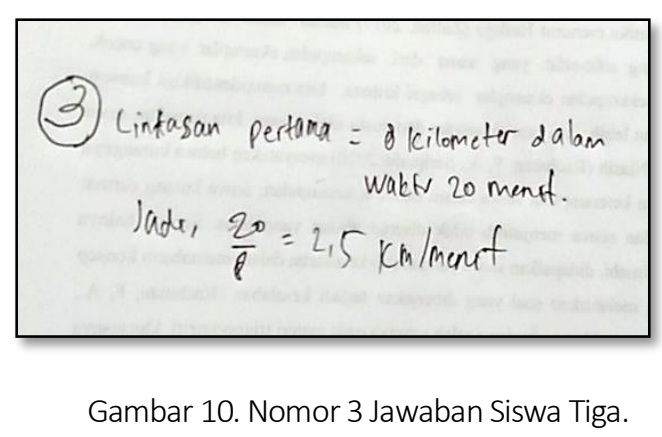

Pada Gambar 10, siswa langsung saja menjawab tanpa memahami soal terlebih dahulu, dan konsep yang digunakan siswa 
tersebut terbalik. Saat diwawancara, siswa tidak suka soal terlalu panjang dan banyak angka-angka, sehingga menyebabkan siswa kurang memahami soal. Siswa juga kurang menguasai materi dan konsep, sehingga siswa menjawab semampunya saja. Hal ini sesuai dengan penelitian Widdiharto (Dwidarti, Mampouw, \& Setyadi 2019) bahwa kesulitan dalam matematika ditandai oleh tidak mengingat satu syarat atau lebih dari suatu konsep. Hal ini menujukkan bahwa siswa masih mengalami kesulitan untuk memahami suatu materi dalam matematika. Penyebab kesulitan tersebut karena siswa tidak menguasai konsep, serta tidak dapat membedakan permasalahan perbandingan senilai dan perbandingan berbalik nilai. Hal ini sejalan dengan penelitian Rismayantini, Kadarisma, \& Rohaeti (2021) dan Puspithasari \& Pujiastuti (2021).

\section{Penutup}

Berdasarkan hasil analisis data yang telah dilakukan peneliti, disimpulkan bahwa pembelajaran siswa SMP kelas VII pada materi perbandingan yang menggunakan pendekatan kontekstual belum berhasil. Siswa masih mengalami beberapa kesulitan maupun kendala saat dihadapkan dengan soal-soal yang berbentuk kontekstual. Faktorfaktor atau penyebab yang dialami siswa yaitu rendahnya kemampuan siswa dalam memahami soal ataupun permasalahan, kurangnya pemahaman konsep matematika, dan siswa masih belum bisa melakukan proses perhitungan dengan benar. Selanjutnya berdasarkan wawancara, diketahui bahwa soal cerita merupakan sajian permasalahan yang sulit dicerna, sehingga dalam menyelesaikan permasalahan tersebut siswa tidak bisa menuntaskan jawaban sampai pemecahan masalah.

\section{Daftar Pustaka}

Anggoro, S, B. (2016). Analisis Persepsi Siswa SMP terhadap Pembelajaran Matematika Ditinjau dari Perbedaan Gender dan Disposisi Berpikir Kreatif Matematis. AlJabar: Jurnal Pendidikan Matematika. 7(2), 153-166.

Afriansyah, A, E., (2017). Problem Posing Sebagai Kemampuan Matematis. Mosharafa: Jurnal Pendidikan Matematika, 6(1), 163-180.

Afriansyah, A, E., (2017). Desain Lintasan Pembelajaran Pecahan Melalui Pendekatan Realistic Mathematics Education. Mosharafa: Jurnal Pendidikan Matematika, 6(3), 463-474.

Agnesti, Y., \& Amelia, R., (2020). Penerapan Pendekatan Kontekstual dalam Menyelesaikan Soal Cerita pada Materi Perbandingan dan Skala terhadap Siswa SMP . Mosharafa: Jurnal Pendidikan Matematika, 9(2), 347-358.

Agnesti, Y., \& Amelia, R., (2020). Analisis Kesalahan Siswa Kelas VII SMP Dalam Menyelesaikan Soal Cerita Pada Materi Perbandingan Ditinjau Dari Gender. Jurnal Cendekia: Jurnal Pendidikan Matematika, 4(1), 151-162.

Aripin, U. (2018). Analisis kesalahan siswa dalam menyelesaikan soal cerita bangun datar segiempat ditinjau dari 
kemampuan pemecahan masalah matematik untuk siswa kelas VII.JPMI (Jurnal Pembelajaran Matematika Inovatif), 1(6), 1135-1142.

Darjiani, N. N. Y., Meter, I. G., \& Negara, I. G. A. O. (2015). Analisis Kesulitan-Kesulitan Belajar Matematika Siswa Kelas V Dalam Implementasi Kurikulum 2013 di SD Piloting Se-Kabupaten Gianyar Tahun Pelajaran 2014 / 2015. E-Journal PGSD Universitas Pendidikan Ganesha, 3(1), 111.

Durandt, R., \& Jacobs, G. J. (2018). Exploring the initial convictions and mindset of prospective mathematics teachers towards modelling. In Educating Prospective Secondary Mathematics Teachers (pp. 307-324). Springer, Cham.

Dwidarti, U., Mampouw, L. H., \& Setyadi, D., (2019). Analisis Kesulitan Siswa Dalam Menyelesaikan Soal Cerita Pada Materi Himpunan. Journal Cendekia: Jurnal Pendidikan Matematik, 3(2), 315-322.

Ferdianto, F., \& Yesino, L., (2019). Analisis Kesalahan Siswa dalam Menyelesaikan Soal Pada Materi SPLDV Ditinjau dari Indikator Kemampuan Matematis. SJME: Supremum Journal of Mathematics Education), 3(1), 32-36.

Fouze, A. Q., \& Amit, M. (2017). Development of mathematical thinking through integration of ethnomathematic folklore game in math instruction. EURASIA Journal of Mathematics, Science and Technology Education, 14(2), 617-630.

Fujii, T. (2018). Lesson study and teaching mathematics through problem solving: The two wheels of a cart. In Mathematics lesson study around the world (pp. 1-21). Springer, Cham.

Hamidah, D., Putri, R. I. I., \& Somakim, S. (2018). Eksplorasi Pemahaman Siswa pada Materi Perbandingan Senilai Menggunakan Konteks Cerita di SMP. Jurnal Riset Pendidikan dan Inovasi Pembelajaran Matematika (JRPIPM), 1(1), 1-10.

Herminingtyas, R. E. (2019). Peningkatan Aktivitas dan Hasil Belajar Siswa pada Kompetensi Dasar Soal Cerita Perbandingan melalui Metode Scientific. Media Penelitian Pendidikan: Jurnal Penelitian dalam Bidang Pendidikan dan Pengajaran, 13(2), 157162.

Indarwati, I., Wahyudi, \& Ratu, N., (2014). Peningkatan Kemampuan Pemecahan Masalah Matematika Melalui Penerapan Problem Based Learning Untuk Siswa Kelas V SD. Satya Widya: Jurnal Penelitian Pengembangan Kependidikan, 30(1), 1727.

Irawatie, A., Iswahyuni, I., \& Setyawati, M. E. (2019). Education learning development of character education-based state defense. International Journal of Multicultural and Multireligious Understanding, 6(8), 27-42.

Khusna, H., \& Ulfah, S., (2021). Kemampuan Pemodelan Matematis dalam Menyelesaikan Soal Matematika Kontekstual. Mosharafa: Jurnal Pendidikan Matematika, 10(1), 153-164. Komara, E. (2017). Curriculum and Civic Education Teaching in Indonesia. EDUCARE, 10(1). 
Larasati, Y., \& Mampouw, L, H., (2018).

Pemberian Scaffolding Untuk

Menyelesaikan Soal Cerita Materi

Perbandingan Senilai Dan Berbalik Nilai.

Math Didactic: Jurnal Pendidikan

Matematika, 4(1), 47-56.

Mulyadin, E., Sowanto, S., \& Dusalan, D. (2020). Pengembangan Perangkat Pembelajaran CIRC (Cooperative Integrated Reading and Composition) dalam Meningkatkan Pemahaman Matematis Pada Materi Perbandingan Siswa SMP.SUPERMAT (Jurnal Pendidikan Matematika), 4(1), 40-51.

Novriani, M. R., \& Surya, E. (2017). Analysis of student difficulties in mathematics problem solving ability at MTS SWASTA IRA Medan. International Journal of Sciences: Basic and Applied Research (IJSBAR), 33(3), 63-75.

Puspithasari, H. D., \& Pujiastuti, H. (2021). Analysis of Students' Understanding of Mathematical Concepts in Solving Comparative Problems. Journal of Medives: Journal of Mathematics Education IKIP Veteran Semarang, 5(1), 181-188.

Putri, D. A., Winarni, R., \& Surya, A. (2021). Analisis kesulitan belajar pemecahan masalah matematika berdasarkan newman procedure pada peserta didik kelas $\mathrm{V}$ sekolah dasar. Didaktika Dwija Indria, 9(3).

Qizi, F. N. F. (2021). Modernization Of Uzbek Language and National-Spiritual Heritage In National Culture. The American Journal of Social Science and Education Innovations, 3(01), 585-594.

Rofi'ah, N., Ansori, H., Mawaddah, S. (2019). Analisis Kesalahan Siswa dalam MenyelesaikanSoal Cerita Matematika Berdasarkan Langkah Polya. EDU-MAT: Jurnal Pendidikan Matematika, 7(2), 120129

Rahayu, P., Mardiyana, \& Saputro, S. R. D., (2015). Eksperimentasi Model Problem Based Learning Dan Discovery Learning Pada Materi Perbandingan Dan Skala Ditinjau Dari Sikap Peserta Terhadap Matematika Didik Dikelas VII SMP Kabupaten Klaten Tahun Pelajaran 2013/2014. Jurnal Elektronik Pembelajaran Matematika, 3(3). 242256.

Rismayantini, R., Kadarisma, G., \& Rohaeti, E. E. (2021). Analisis Epistemological Obstacle pada Materi Perbandingan Siswa SMP Kelas VIII.JPMI (Jurnal Pembelajaran Matematika Inovatif), 4(1), 81-90.

Saputri, R. A. (2019). Analisis pemecahan masalah soal cerita materi perbandingan ditinjau dari aspek merencanakan Polya. Majalah Ilmiah Kependidikan, 3.

Sari, N. M. (2020). Analisis Kesulitan Siswa Dalam Mengerjakan Soal Matematika Materi Perbandingan Kelas VII SMP Luhur Baladika.Jurnal Equation: Teori dan Penelitian Pendidikan Matematika, 3(1), 22-33.

Shanta, S., \& Wells, J. G. (2020). T/E design based learning: assessing student critical thinking and problem solving 
abilities. International Journal of

Technology and Design Education, 1-19.

Simamora, R. E., Sidabutar, D. R., \& Surya, E. (2017). Improving learning activity and students' problem solving skill through problem based learning (PBL) in junior high school. International Journal of Sciences: Basic and Applied Research (IJSBAR), 33(2), 321-331.

Surya, E., \& Putri, F. A. (2017). Improving mathematical problem-solving ability and self-confidence of high school students through contextual learning model. Journal on Mathematics Education, 8(1), 85-94.

Toha, M., Mirza, A., \& Ahmad, D. (2018). Analisis Kesalahan Siswa Dalam Menyelesaikan Soal Cerita Materi Perbandingan Di Kelas VII SMP.

Utari, D. R., Wardana, M. Y. S., \& Damayani, A. T. (2019). Analisis Kesulitan Belajar Matematika dalam Menyelesaikan Soal Cerita. Jurnal IImiah Sekolah Dasar, 3(4), 534-540.

Verschaffel, L., Depaepe, F., \& Van Dooren, W. (2020). Word problems in mathematics education. Encyclopedia of mathematics education, 908-911.

Walkington, C., Clinton, V., \& Sparks, A. (2019). The effect of language modification of mathematics story problems on problem-solving in online homework. Instructional Science, 47(5), 499-529.

Yuanita, P., Zulnaidi, H., \& Zakaria, E. (2018). The effectiveness of Realistic Mathematics Education approach: The role of mathematical representation as mediator between mathematical belief and problem solving. Plos one, 13(9), e0204847.

Yuliani, W. (2018). Metode penelitian deskriptif kualitatif dalam perspektif bimbingan dan konseling. Quanta, 2(2), 83-91.

Yustianingsih, R., Syarifuddin, H., \& Yerizon, Y. (2017). Pengembangan Perangkat Pembelajaran Matematika Berbasis Problem Based Learning (PBL) untuk Meningkatkan Kemampuan Pemecahan Masalah Peserta Didik Kelas VIII. JNPM (Jurnal Nasional Pendidikan Matematika), 1(2), 258-274.

\section{Riwayat Hidup PenUlis Yuni Agnesti, S.Pd.}

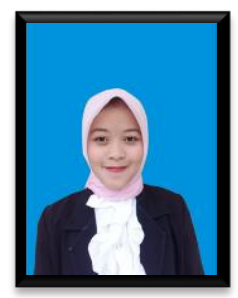

Lahir di Bandung, 16 Agustus 1997. Staff Pengajar di SMP Pasundan Rongga. Studi S1 Pendidikan Matematika Ikip Siliwangi Cimahi.

Risma Amelia, M.Pd.

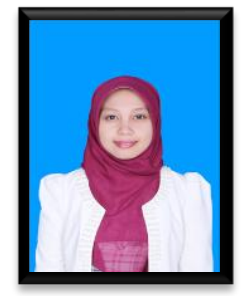

Lahir di Sukabumi, 20 maret 1991. S1-S2 program studi pendidikan matematika STKIP Siliwangi. Bekerja sebagai dosen tetap sejak tahun 2013 sampai sekarang, dan menjadi Sekretaris Dekan Fakultas Pendidikan Matematika Sains sejak tahun 2018 di IKIP Siliwangi. 